MARITIME SEDIMENTS AND ATLANTIC GEOLOGY

$18,41-58(1982)$

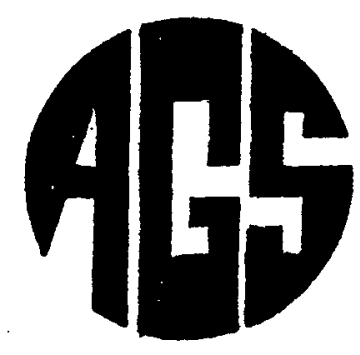

\title{
THE ATLANTIC GEOSCIENCE SOCIETY COLLOQUIUM \\ on \\ Current Research in the Atlantic Provinces
}

\section{ABSTRACTS}

The biannual colloquium on Current Research in the Atlantic Provinces held by the Atlantic Geoscience Society took place in Amherst, Nova Scotia on January 22 and 23, 1982. The meeting attracted well over 100 participants from a wide cross-section of the geological fraternity with 28 papers presented in addition to 11 poster sessions. The standard and presentation of the papers were both excellent, thus demonstrating that both the society and its members are actively involved in some highly original and fascinating research. The society wishes to thank Dr. Laing Ferguson for his excellent organization of the meeting and Cominco Ltd., John A. Leslie and Associates Ltd. and Noval Technologies Ltd. for their help in sponsoring the meeting. The following abstracts represent papers presented at the colloquium. 


\title{
Wellsys: a well information database
}

\author{
M. Douma \\ Eastern Petroleum Geology Subdivision, AGC, Dartmouth, N.S.
}

Development of a prototype database of offshore well information was begun in the spring of 1981, using a commercially available software package called System 2000 .

The database consists of well information, both observed and interpreted, structured in an easily retrievable format. Original information, such as engineering data, wireline $\log$ information, and test data, is obtained from the well history reports submitted to the federal government by the operators. Interpreted information, such as maturation studies, and lithostratigraphic and biostratigraphic analyses, is ob- tained from published reports, most commonly, those of the GSC.

A major portion of the database is given over to bibliographic information on all publications concerning the wells. It is important that all information in the database be traceable to its source. Should the database be unable to answer a specific question, the location of more basic data is shown.

As a prototype, the well information database is subject to revisions and modifications to the structure. These would be undertaken to enhance the usability of the system by persons other than computer scientists.

\section{Tectonic implications of regional gravity studies in the Central Carboniferous Basin, New Brunswick}

\author{
J. Chandra, J. Wallace and S. Chandra \\ Department of Natural Resources, Fredericton, N.B. E3B $2 R 7$
}

In 1980, Regional, Residual and 2nd Derivative gravity maps $(1: 250,000$ scale) of New Brunswick were compiled from approximately 7000 gravity data points published by the Earth Physics Branch (E.M.R.). This data base has increased to 20,500 points as a result of an accelerated gravity mapping project undertaken by the New Brunswick Department of Natural Resources. The writers are now in the process of computing a new set of gravity maps utilizing the larger data base.

Interpretation of the 1980 gravity maps indicate very close correlation of major faults with well defined gravity linears in both Carboniferous and Pre-Carboniferous strata. Perhaps the most important aspect of this correlation however, is the delineation of major gravity lows forming distinct linear patterns in the Central Carboniferous Basin. The writers have interpreted these northeasterly striking features of alternating gravity highs and lows as horst and graben structures in the Pre-Carboniferous basement. Five major grabens are proposed of which at least two are associated with coal deposits identified from drilling. Distinct differences in the palynmorphs present over short distances support a horst and graben mode1. Major northwesterly trending faults have also been delineated by the filtered gravity data and are identified by the abrupt changes and breaks in the "horst-graben" trends identified in the Residual and 2nd Derivative maps.

Confirmation of the horst and graben structures will aid in assessing the mineral potential and also provide possible targets for further drilling in the Central Basin. To this end, integrated studies of magnetic, gravity, seismic and geologic data are underway in the region. 


\title{
Cambro-Ordovician trace fossils from Bell Island, eastern Newfoundland
}

\author{
Denis Fillion and Ron $K$. Pickerill \\ Department of Geology, University of New Brunswick, Fredericton, N.B. E3B 5A3
}

Cambro-Ordovician strata of Bell Island, eastern Newfoundland, are composed of a siliclastic sequence which was deposited in a series of tidal flat, offshore barrier or tidal bar and lagoonal environments. Though relatively poor in terms of body fossils, the sequence contains an abundant and diverse trace fossil assemblage. Thus far, the following trace fossils have been recognized: Arthraria, Bergaueria, six species of Cruziana, Dactylophycus, Dimorphichnus, Diplichnites, Diplocraterion, Gordia, Gyrolithes, Helminthopsis, Isopodichnus, Monomorphichnus, Palaeophycus, Phycodes,
Planolites, five species of Rusophycus, Skolithos, Teichichnus, Trichichnus and Trichophycus. Tentatively identified traces include: Arenicolites, Cylindrichnus, Mammillichnis, Monocraterion and Pelecypodichnus.

Though research is by no means complete, particularly in terms of detailed taxonomy, the trace fossils can be broadly correlated with specific environments within the sequence. The excellent preservation of the majority of trace fossils permits insight into some current problems of nomenclature in ichnology.

\section{Barrier overwash and washover sedimentation Aspy Bay, Cape Breton Island}

\author{
D.L. Forbes, R.B. Taylor and D. Frobel \\ Atlantic Geoscience Centre, Bedford Institute of Oceanography, \\ Dartmouth, N.S. B2Y $4 A 2$
}

Storm overwash is an important process affecting the modern Aspy Bay barrier system and washover sediments form a major component of the barrier deposit. Overwash occurs as a unidirectional episodic nonuniform surge when wave uprush overtops the berm. Due to rapid infiltration, many overwash flows do not reach the lagoon; however, interstitial or surface ice in winter may prevent infiltration, increasing the frequency and extent of overwash. Where extensive overtopping occurs, washover transport forms sheet-1ike deposits; elsewhere the overwash is laterally confined and the washover sediments form channel fills terminating in thin fans or deltas. Although the distribution of washover channels on the 4-km barrier fronting North Aspy Pond remained essentially fixed over a 3-year interval 1966-1969, major changes in the location and morphology of washover features occurred between each of four sets of air photos taken in 1939, 1947, 1953 and 1966. The proportion of total barrier length subject to overwash remained relatively constant at $46-52 \%$ over the 30 -year interval spanned by the photographs. Scour-fill sequences were monitored in two washover channels during OctoberNovember 1.981 to determine the relative importance of overwash and wind transport. Reworking of washover sediments by strong winds directed both on- and offshore was not a significant factor in the evolution of the channels during the study period. On the other hand gravel lag deposits in some areas of the barrier backshore are attributed to aeolian deflation of washover sediments. Four storms during the 2-month field program generated overwash scour and fill events that resulted in deposition of composite distal-thinning washover units with a maximum observed thickness of $263 \mathrm{~mm}$. Washover sediments are predominantly subparallel-laminated sands dipping $1.5-1.9^{\circ}$ toward the lagoon. The thickness of individual sedimentation units ranges from order $10^{\circ}$ to $10^{1} \mathrm{~mm}$. Some units appear to exhibit inverse textural grading consistent with a grainflow transport process. Small inbri- 
cate groupings and isolated clasts of pebble- and cobble-size material are common but not abundant in the washover sands. Critical boundary shear stress for the coarsest particles if of the order of $10^{1}-10^{2} \mathrm{~N} \mathrm{~m}^{-2}$, allowing for an overloose condition at entrainment. Ex- treme distal washover deposits include planar cross-stratified foreset sand units up to $200 \mathrm{~mm}$ thick. It is assumed that primary structures of washover fans deposited on winter ice in the lagoon are not preserved in the final deposit after breakup.

\title{
Post-depositional mud migration structures in the Tynemouth Creek Formation; Lower Pennsylvanian, southern New Brunswick
}

\author{
G. Plint and H.W. van de Poll, Department of Geology \\ University of New Brunswick, Fredericton, N.B. E3B $5 A 3$
}

The Tynemouth Creek Formation is of lower Pennsylvanian age (Westphalian B?) and is exposed on the south coast of New Brunswick, between St. Martins and Saint John. The formation dominantly comprises red mudstones, sandstones and conglomerates and represents a proximal alluvial fan of southeasterly derivation.

Evidence of physical diagenesis, in the form of post-depositional migration of mudstone is abundant and may be grouped, for the purposes of description, into four principal types all of which are intergradational. These comprise: Load Deformation, Mud Intrusions, Mud Injection Laminae and Brecciforms.

Load Deformation occurs at sand/mud interfaces where the two sediments remain essentially contiguous. They reflect relatively high sediment viscosities at the time of loading.

Mud Intrusions involve the rupturing and penetration of sandstone beds by discrete masses of mud which may be several metres in diameter. In conglomerates, however, intruded mud forms more diffuse bodies in which mud has permeated between individual clasts.

Mud Injection Laminae (M.I.L.) are the most commonly occurring physical diagenetic structures in the Tynemouth Creek Fromation. Mud injection laminae comprise irregular ramifying mud sheets which range up to $10 \mathrm{~mm}$ in thickness. They are most common in fine and mediumgrained sandstones, to which they impart a form of pseudo-bedding. M.I.L. may have any orientation to bedding, and occasionally may form conical sheets. M.I.L. are often cut by small, sandfilled cracks. The penetrative nature of M.I.L. suggests that they result from the injection of very fluid mud.

Brecciforms comprise discrete blebs of mud dispersed through structureless sandstone. Blebs are generally ovoid, sharp-walled and have a micro-fabric resembling cleavage. Brecciforms are thought to form by the immiscible interflow of relatively cohesive mud into liquidfied sand; immiscibility permitting globules of mud to migrate freely through the isotropic host sediment.

In all four cases, mud injection took place under the influence of reversed density gradients, compounded by high pore-fluid pressures and high lithostatic load. Each class of structure is simply a response to a particular combination of physical conditions, mainly density, viscosity and cohesion. In a broader context, abundant evidence of mud migration is probably a reflection of rapid rates of subsidence and sedimentation leading to the accumulation of thick sequences of under-compacted sediments with unstable density and pore-fluid pressure gradients.

Experiments are under way to replicate physical diagenetic structures. Although in their early stages, these experiments have already been successful in illustrating the genetic mechanisms of some diagenetic structures. 


\title{
Implications of structural studies in eastern Notre Dame Bay: evidence for an allochtonous Dunnage Zone
}

\author{
K.E. Karlstrom, B.A. van der Pluijm and P.F. Williams \\ Department of Geology, University of New Brunswick, Fredericton, N.B. E3B 5A3
}

Many workers have interpreted Newfoundland's Dunnage Zone as "rooted", believing it to be an authochthonous remnant of the Paleozoic Iapetus Ocean preserved due to "incomplete suturing" during plate collision. We consider this interpretation to be incompatible with both structural and geophysical evidence.

Our structural studies in northeastern Newfoundland indicate that $F_{1}$ deformation of Ordovician and Silurian rocks involved macroscopic thrust faulting. When combined with published evidence for Silurian-Devonian thrusting along the Baie Verte-Brompton Line, along the Lobster Cove Fault in Western Notre Dame Bay, and in the Bay d'Espoir area of southern Newfoundland, these findings indicate major post-Lower Silurian orogenesis throughout the Dunnage zone. Significantly, Silurian rocks on the Port Albert Peninsula previously interpreted to be post-orogenic subaerial units were also involved in thrusting. Our interpretation of the structural style of eastern Notre Dame Bay is that of a series of refolded nappes. At least major portions of the Dunnage Zone are allochthonous.

Gravity data indicate that the Dunnage
Zone as a whole cannot be autochthonous. The observed Bouguer anomaly over the zone has maximum values of $30-40$ mgals and local highs within the zone correspond closely with surface exposures of ophiolite. Published gravity models account for the observed anomalies using slabs of ophiolitic material (density $2.9-3.0 \mathrm{gm} / \mathrm{cm}^{3}$ ) both at the surface and extending to maximum depths of 5-10 $\mathrm{km}$. The important point: is that these ophiolites must be decoupled from most of the oceanic mantle on which they formed and now rest on rocks with densities corresponding to continental crust $\left(2.7-2.8 \mathrm{gm} / \mathrm{cm}^{3}\right)$.

Calculated gravity anomalies based on published cartoons of a "rooted" Dunnage Zone (e.g. showing more than 5-10 km of oceanic crust or appreciable volumes of oceanic mantle below the Dunnage Zone), are hundreds of mgals too large.

The most reasonable interpretation is that oceanic rocks of the Dunnage zone are confined to the upper 5-10 km of crust and are in thrust contact with underlying continental crust. The asymmetry of observed anomalies can be fit by models involving a southeast-dipping basal decollement overlain by a sequence of thrust slices.

\section{Lithologies at the Pennsylvanian/Pre-Pennsylvanian contact in New Brunswick}

\author{
M.C. Graves, Department of Geology \\ Dalhousie University, Halifax, N.S. B3H $3 J 5$
}

Field work in the summer of 1981 together with information provided by test holes of the Carboniferous Drilling Project provide a unified view of the nature of the lower contact of the Pictou Group 1ithologies that cover $35 \%$ of New Brunswick.

The major Carboniferous 1ithologies at the contact are (1) the Hopewell lithology of red, poorly-sorted, lithic conglomerates with a local provenance; (2) the Boss Point lithology of grey, mature clastic rocks of three varieties - (2a) Boss Point Formation thick sandstone-siltstone-shale sequences, (2b) quartz-pebble conglomerate and (2c) clean, quartz sandstone of a A Member of the Clifton Formation -; and (3) the Pictou lithology of green and red lithic 
conglomerates and coal seams. Basalt occurs locally at or near the top of the Hopewell lithology and a buff hard siltstone rests atop the Hopewell lithology in portions of the central part of the New Brunswick Platform.

The three Boss Point sub-1ithologies have distinct outcrop areas. The clean quartz sandstone is restricted to the northern-most portion of the outcrop area between Bathurst and Red Bank on the Little Southwest Miramichi River and lies stratigraphically between Late $\mathrm{Na}$ murian Hopewell lithology and Pictou lithology of Westphalian $C$ age. The quartz-pebble conglomerate is a thin unit which outcrops in the western portion of the New Brunswick platform to the west of Bloomfield Ridge on the Southwest Miramichi River and Upper
Thornes Brook near New Canaan. Late Namurian to Early Westphalian ages have been reported from pollen assemblages collected from this unit. In the southern part of the Moncton Basin and in the Cumberland Basin thick sequences of Boss Point Formation span the mid-Namurian to Westphalian $\mathrm{C}$ interval. The Boss Point Formation is typified by mature and ubiqutously cross-bedded grey sandstones and shale, as well as beds with a high content of coalified plant fossils.

This project was a part of the Carboniferous Drilling Project which was a Federal - Provincial Development Project funded under the Minerals and Fuels Subsiduary Agreement of the Canada-New Brunswick Genera1 Development Agreement by the Government of New Brunswick and the Department of Regional Economic Expansion.

\title{
Chaotic rocks at Carmanville, Newfoundland: problems of terminology and interpretation
}

\author{
J.W.F. Waldron, Department of Geology \\ Saint Mary's University, Halifax, N.S. B $3 H$ 3C3
}

The Carmanville Melange is part of the Ordovician Davidsville Group in NE Newfoundland. It consists mainly of "blocks" of coarse sediment immersed in a fine-grained "matrix". A slaty cleavage is strongly developed in the matrix, but is also seen in blocks, in non-chaotic parts of the Davidsville Group, and in acid dykes cutting both.

Melange is commonly defined as a mappable rock-unit characterized by blocks (including exotic materia1) immersed in a fine-grained matrix with a tectonic fabric. Although the Carmanville Melange corresponds to this definition, the main fabric in the matrix is clearly unconnected with the development of chaotic structure. Demonstratably exotic blocks are very rare in much of the Melange.

The Carmanville Melange has been described as an olistostrome: a chaotic sedimentary rock produced by submarine sliding. It has also been interpreted as the product of deformation within a thick pile of wet sediment (Note: this is not an olistostrome). A third possible model would involve deformation of lithified. but mechanically heterogeneous material.

Distinguishing between these possibilities is difficult because of later deformation. However, four features of the Melange favour the olistostrome model.

(1) Chaotic units are layers concordant with the regional bedding envelope.

(2) There is a continuum between thingraded beds of mudstone-clast conglomerate and layers of more chaotic matrix-rich melange.

(3) Lamination in adjacent sediments overlaps round blocks protruding from the melange surface.

(4) Adjacent cross-laminated siltstones contain outsize sandstone clasts, explicable only as glacial dropstones or as reworking products of olistostromes. 


\title{
Structural analysis in eastern Notre Dame Bay
}

\author{
Ben van der Pluijm, Karl Karlstrom and Paul Williams \\ Department of Geology, University of New Brunswick, Fredericton, N.B. E3B $5 A 3$
}

Structural studies in Ordovician and Silurian rocks in eastern Notre Dame Bay, NE Newfoundland, show three regionally developed fold generations.

$F_{1}$ folds had shallowly dipping axial planes and appear to be related to both meso- and macroscopic thrusting. $F_{2}$ folds are asymmetrical with moderately to steep1y SE dipping axial surfaces. A regional NE-SW trending cleavage $\left(S_{2}\right)$ is axial planar. $F_{2}$ fold axes vary in plunge but are dominantly sub-horizontal. $\mathrm{F}_{3}$ folding involves kinking of $\mathrm{S}_{2}$ regional cleavage with local development of a $\mathrm{S}_{3}$ crenulation cleavage. $\mathrm{F}_{3}$ appears to be realted to faulting.

Macroscopic (km-scale). $F_{1}$ folds are found on Change Islands and New World Island. Macroscopic $F_{2}$ folds are found throughout Notre Dame Bay and include an anticlinorium cored by the Dunnage
Melange and a synclinorium cored by the Botwood Group in the investigated area. Macroscopic $F_{3}$ folding resulted in a gentle warping of the regional cleavage.

We emphasize the following points:

- rather than interpretating the area in terms of tectonostratigraphic zones, we demonstrate a similar deformation history throughout the area.

- the presently mapped major faults in the area are post $-\mathrm{F}_{2}$ features and they cross-cut $F_{2}$ folds, with the faults at a high angle to the $F_{2}$ enveloping surface. These faults include the Chanceport, Lukes Arm, Dildo and Reach Faults.

- all three fold generations involve Lower Silurian rocks and are thus most likely of post-lower Silurian age. We see no direct evidence for "Taconic" deformation.

\section{Research at the Atlantic Geoscience Centre, Geological Survey of Canada Bedford Institute of Oceanography}

\author{
M.J. Keen, Geological Survey of Canada \\ Atlantic Geoscience Centre, Dartmouth, N.S. B2Y $4 A 2$
}

The Atlantic Geoscience Centre is a Division of the Geological Survey of Canada, and one of the constituent laboratories of the Bedford Institute of Oceanography in Dartmouth. The Centre has the general responsibility within the Federal Government to provide advice and information on a large part of Canada's offshore and on the sedimentary basins of eastern Canada. As a result, it undertakes a variety of research programs ranging from studies of pyrite in coals in Nova Scotia to scour by icebergs on the Labrador Shelf. The work which it does falls into several broad categories:

(1) Studies of the sedimentary basins onshore: these include studies of the coals and oil shales of eastern Canada and the biostratigraphy of the Permo-
Carboniferous rocks.

(2) Studies of the Mesozoic/Cenozoic wedge of the continental margin offshore and of the gross earth structure associated with the margin.

(3) Studies of the ocean basins nearby such as the Labrador Sea and the Artic Ocean.

(4) Studies of modern marine geological processes: this work includes topics such as sedimentation of the Bay of Fundy, scour by ice in the offshore, and the distribution and origin of surficial sediments in the offshore in genera1.

Particular examples of current research will be used to illustrate their range, variety and use. 


\title{
Stratigraphy, sedimentation and basin evolution of the Pictou Group (Pennsylvanian), Fredericton Sub-Basin, New Brunswick, Canada
}

\author{
Christopher J. Le Gallais, Department of Geological Sciences \\ MCGill University, Montreal, Quebec $H 3 A 2 A 7$
}

Recent core drilling programs in the Fredericton area $(9,946 \mathrm{~m})$ are the first to provide enough concentrated subsurface data to examine and reconstruct models of facies distribution and correlation in the Pennsylvanian Pictou Group (Westphalian C-D, Stephanian age) in the southwestern portion of the Central Carboniferous Basin, New Brunswick.

The vertical stratigraphy of the Pictou Group in the Fredericton area consists of three distinct megacyclic units ranging from 200 to 450 metres in individual thickness. Megacycles I and II are characterized by a predominantly coarse-grained grey-coloured reduced lithofacies assemblage at the base, and a finer-grained dominantly red-coloured oxidized lithofacies assemblage at the top. Megacycle III consists of stacked smaller scale cycles (10-75 m thick) of similar character.

The reduced lithofacies assemblage is attributed to sedimentation in a braid plain environment dominated by the deposition of sand and conglomerate in multiple stacked channel facies sequences. The borderlands adjacent to these fluvial channel facies were essentially below the mean water table and are dominated by carbonaceous shales and siltstones deposited in lacustrine and backswamp environments. The oxidized lithofacies assemblage is attributed to deposition on a semi-arid alluvial plain with isolated sand channel facies, calcrete and pisolitic laterite horizons in a mud-dominated succession. The presence of desiccation cracks, root zones and laterites containing calcareous nodules, caliche crusts and pisolites suggests soil development above the water table. The development of thin but laterally persistent layers of coalified organic material indicates the periodic development of restricted ephemeral lakes or swamps by a rise in the base water table.

Preliminary work appears to suggest that both the reduced and oxidized lithofacies assemblages occurred simultaneously within the Fredericton sub-basin at least during some periods of time. Vertical and lateral variations in the megacyclic stratigraphy cannot be explained by simple climatic variation but are interpreted to represent mainly the product of dynamic inter-reaction between the braid plain and alluvial plain "depositional systems".

\section{Correlation and proximate analysis and depth to methane content of coals in the Pictou Basin}

\author{
A.J.P. Thompson \\ Noval Technologies Ltd., Halifax, N.S.
}

In 1980, Noval Technologies conducted a diamond drill program to obtain coal core from the Pictou Coalfield for methane content evaluation. The direct method for methane evaluation was used. Proximate analysis was conducted on the coal when methane measurement was completed.

The data was analyzed for possible correlations between the measured methane content and depth and proximate analysis. Some correlations were observed and attempts were made to derive an equation for predicting methane content using depth and proximate analysis.

A discussion on the correlations observed, the attempts to derive the predicted equation, and the future application of such an equation will be presented. 


\title{
Cambrian medusoids from the Saint John Group, southern New Brunswick
}

\author{
R.K. Pickerill, Department of Geology \\ University of New Brunswick, Fredericton, N.B. E3B $5 A 3$
}

Since the pioneering work by G. F. Matthew, Cambrian strata of Saint John and adjacent areas, southern New Brunswick, have attracted palaeontological research for almost a century. The newly constructed McKay Highway has provided new and important exposures of Cambrian strata within the City of Saint John. One such exposure, located northwest of Courtenay Bay in east Saint John, has yielded over 100 specimens of moderately well-preserved medusoids (jellyfish - sensu lato) on the upper surface of a ripple marked quartz arenite.

Unfortunately, because of the deplorable and improper stratigraphic nomenclature adopted for the succession here, i.e. the acceptance of biostratigraphical units for formational subdivision, it is impossible to state with certainty the exact age of the medusoids as the only associated fossils are poorly preserved lingulid brachiopods. It is argued, however, that they most likely occur in the Agnostus Cove Formation of lower Upper Cambrian age. As Cambrian medusoids in Canada have only been previously described from the Burgess Shale, the locality represents a most unique and fortunate discovery. If instituted, it should, if possible, be given priority as a protected site.
A more serious difficulty arises with classification of the medusoids as either hydrozoan or scyphozoan. Most palaeontologists have historically and specifically attributed medusoids to one or other of these unrelated classes, but based on few and non-biological diagnostic criteria. Indeed, realistically, their differentiation is largely dependent on basicbiological differentiating parameters e.g. does the coelenteron bear gonads, gastric filaments and pouches, is the medusoid craspedote (possesses a velum), are subumbrella furrows present? etc. Unfortunately, fossil medusoids are only known from one side (umbrella or subumbrella), exhibit varying degrees of decomposition which influences their shape and structure, frequently exhibit superimposition of umbrella and subumbrella features, are sometimes akin to basal discoidal attachments in known benthonic cnidarians and often do not preserve 'biological' differentiating criteria. Although the Saint John medusoids do not preserve direct evidence of a scyphozoan or hydrozoan affinity, their size, preservation and radial canals in multiples of 12 or 16 suggest affinities to the scyphozoans. The research is by no means complete but it is likely that they represent a new species.

\section{GEOSCAN, the national database for geological information}

\author{
N.A. Lyttle, Mineral Resources Division \\ Nova Scotia Department of Mines and Energy, Halifax, N.S.
}

GEOSCAN, the national database for geological information, is a bibliographic database controlling Canadianproduced and/or Canada-related geoscience documents. Created in 1969, the database currently contains 65,624 records. GEOSCAN is somewhat of a unique venture in that it represents the products of twelve years of joint, cooperative efforts between participating federal and provincial geoscience agencies, and contains a high percentage $(66 \%)$ of unpublished items. The Nova Scotia Department of Mines and Energy is an active participant in GEOSCAN and has in press several GEOSCAN-derived publications, namely: Indexes to Assessment Reports, Drillhole Locations, Publications, Open File Reports and Theses, covering the period 1862-1980. 


\title{
The possible use of the amplitude of a reflected sound field for the determination of seabed properties
}

\author{
Alasdair G. MCKay \\ Nova Scotia Research Foundation, Dartmouth, N.S. B2Y $3 Z 7$
}

The measurement of the compressional wave velocity in seabed materials has been neglected in most studies which have been carried out on surficial sediments.

Mckay has established methods for making such measurements and these will be incorporated into the second phase of the Bedford Institute Seabed Project for commercial application.

There remains the possibility of extracting some information on seabed properties from the way in which a reflected pressure field will vary in amplitude with the angular separation between a point source and a point receiver. It is unlikely that this amplitude variation can be used to derive values for the seabed properties on which it depends ( $p$ and $s$ wave velocities, density contrast and attenuation) in all circumstances, but it may prove to be a useful empirical diagnostic parameter in some cases.

\section{The evaluation of production potentials of demethanation wells utilizing " "hot-wire" gas detection methods}

\author{
Brian J. McMahon \\ Noval Technologies Ltd., Halifax, N.S.
}

In the fall of 1980 , Noval Technologies began a program to evaluate the potential of a hot-wire (catalytic filament) gas detection unit as a tool to determine the production potentials of demethanation wells. The unit was set up to monitor the gas response of the drilling fluid while drilling six boreholes, three of which were wireline cored exploration holes and three of which were rotary percussion drilled production wells. A hot-wire detector was also used to determine the gas content and relative rates of desorption of cuttings samples from the production we11s.

The results have been successful not only in indicating the production zones, the seam gas content, and the rates of production of seams relative to one another, but have also proved extremely effective for the assessment of drilling problems while on site, and, geologically, for indicating highly fractured zones, fault zones, lithologies and seam correlations.

\section{Slip-sliding away - morphology and process on the Nova Scotian continental slope}

\author{
Philip R. Hill \\ Atlantic Geoscience Centre, Bedford Institute of Oceanography \\ Dartmouth, N.S. B2Y $4 A 2$
}

Detailed studies of small inter-canyon areas of the Nova Scotian Slope show that mass-movements on various scales were important events in the late Pleistocene. The complex morphology, created by slump and slide masses, appears to have controlled subsequent deposition by turbidity currents. Most turbidity currents flowed down a large channel, but depressions with relief of only 10-20 metres contain a significantly higher proportion of coarse-grained (sandy) turbidite beds than the intervening bathymetric highs. Flows generated on 
the upper slope or spilling over the main channel walls are thought to have been diverted by small-scale morphological features and sand deposition to have been concentrated in the depressions. A one to two metre mud drape over most of the area indicates that gravity-driven processes have not been active during the Holocene.
A cruise is planned in 1982 to survey at least one of the areas with the SEAMARC deep-towed sidescan sonar system, built at Lamont to search for the Titanic. SEAMARC has a horizontal range of 5 kilometres, so that mapping of individual features on the slope will be possible.

\title{
Physical diagenesis: a neglected aspect in the reconstruction of. ancient sedimentary environments
}

\author{
H.W. van de Poll and G. Plint, Department of Geology \\ University of New Brunswick, Fredericton, N.B. E3B $5 A 3$ \\ and \\ I. Patel, Department of Geology \\ University of New Brunswick, Saint John, N.B. E2L $4 L 5$
}

In the study of clastic sedimentary rocks, physical diagenesis has received relatively little attention. This is unfortunate because recent work has indicated that physical diagenesis can considerably alter the primary character. of sedimentary sequences, in particular of those that have been deposited in tectonically unstable regions.

As used here physical diagenesis embraces all post-depositional pre-metamorphic changes resulting from dewatering, compaction and sub-surface remobilization of sediments. Conditions governing physical diagenesis include high initial porosity, excessive pore-fluid pressures, rapid sediment accumulation, density inversion and differential viscosities. The principal processes involved are fluidization, liquifaction and elutriation.

A wide range of secondary sedimentary structures can form as a result of physical diagenesis including load deformation, sediment injection, sediment inflow, and sediment interflow structures as well as structures formed from rheoplasis and local fluidization and dilation of the sediments.

It is important to distinguish primary from secondary sedimentary structures. Primary sedimentary structures, as the name implies, reflect primary processes at the sedimentary interface involving sediment transport and deposition. In contrast, secondary sedimentary structures reflect dewatering and the post-depositional rheotropic behaviour of the sediments. They are related to groundwater conditions, subsurface drainage, rate of sediment accumulation and pre-consolidation movement of the sediments during compaction in response to unstable pore-fluid, density and viscosity gradients, and induced shear (earthquake movement). Primary and secondary sedimentary structures, therefore, represent separate aspects of the depositional environment, and for a more complete paleo-environmental reconstruction the information from both classes of structures should be integrated when possible. Recent work has indicated that physical diagenesis can overprint primary stratification, homogenize sediments, amalgamate beds and cause other major changes as a result of compaction and/or post-depositional redistribution of the sediment. It may lead to the development of pre-tectonic deformation structures, such as intrastratal slump-folds and soft sediment fissility and can significantly reduce primary porosity and permeability of potential reservoir rocks by post-depositional clay infiltration into the matrix of coarse-grained sediments. 


\title{
Structural analysis of Tetagouche Group (Ordovician) rocks in a zone between Brunswick no. 12 mine and Austin Brook open pit
}

\author{
Cees van Staal, Department of Geology \\ University of New Brunswick, Fredericton, N.B. E3B $5 A 3$
}

Four generations of folds have been demonstrated. The first generation of folds have a roughly N-S trend, are tight to isoclinal, probably double plunging, and are responsible for transposition of bedding. $\mathrm{F}_{2}$ is characterized by $\mathrm{N}-\mathrm{S}$ trending, asymmetrical $z$-shaped folds plunging steeply to the $S W$ around the Brunswick No. 6 mine. $S_{2}$ is refracted as it crosses $S_{1} . S_{2}$ overprints the dominant macrostructure, viz. the Brunswick anticline, which is therefore interpreted as an $F_{1}$ fold.

The third generation folds are relatively open, moderate to steep west plunging and commonly accompanied by an axial plane crenulation cleavage. The broad S-shaped flexure between Brunswick
No. 12 and No. 6 is interpreted as a macro $\mathrm{F}_{3}$ fold.

Fourth generation of folds are common1y represented by $Z$-shaped kink folds.

The response of the massive sulphides to the intense deformation was (1) development of a tectonic layering parallel to the $F_{1}$ folded surface; locally accompanied by flow of sulphides into low-pressure areas. (2) Remobilization of sulphides during $F_{2}$ and $F_{3}$ especial$1 y$, resulting in sulphide layers and sulphide-bearing veins parallel respective$1 y$ to the axial planes of $F_{2}$ and $F_{3}$ folds.

The macrostructure of Brunswick No. 6 and No. 12 is discussed.

\section{Stratigraphy and paleogeography of the Windsor Group in southern New Brunswick}

\author{
Steven $R$. McCutcheon \\ Department of Natural Resources, Sussex, N.B. EOE IPO
}

The Lower Visean Windsor Group in southern New Brunswick is divisible into six formations and three informal units that have insufficient areal extent to warrant formation status. The six are: Gays River, Macumber, Parleeville, Upperton, Cassidy Lake and Clover Hill Formations. Two Informal units are named: Samp Hill and Demoiselle Creek beds.

The stratigraphic section in the Moncton sub-basin is as follows. The basal limestone consists of shallow-water, basement-fringing, algal buildups (Gays River), in places with intercalated siliciclastics (Parleeville), which are laterally equivalent to deeper-water, very thin to thinly bedded, euxinic, limestone (Macumber). The Macumber is overlain by stratiform, nodular to mosaic, anhydrite (Upperton) that is hosted by carbonate or calcareous siliciclastics. The sulphate also is equivalent, in part, to the algal buildups. Deepwater salts (Cassidy Lake and Clover Hi11) overlie the "basal-anhydrite"; have a basin-centre distribution, and are capped by greenish grey mudstone ("transitional beds"). Thinly bedded, euxinic limestone with interbedded greenish-grey mudstone (Samp Hill) is found between Gays River and "transitional" rocks in the Havelock area, only. All these rocks belong to the $A$ subzone of the Windsor Group.

The remaining units (unnamed and Demoise1le Creek) only occur in the Cumberland Subbasin. The uppermost one (Demoiselle Creek) consists of two carbonate subunits separated by red beds and the lower one (unnamed) is composed entirely of red beds. These rocks be; long to the B subzone of the Windsor Group, not the $C$ subzone-as previously believed. 
The 1ithofacies distribution in the map area indicates (1) the Moncton Subbasin was open to the northeast but not the southwest, (2) the Marysville Subbasin, bordered on three sides by Lower Paleozoic Upland, undoubtedly contains
Windsor rocks in the sub-surface probably as far north as the Fredericton Fault, and (3) the Gays River Formation contains most of the high calcium limestone and all the known base metal sulphide accumulations in the Windsor Group.

\title{
Early Cretaceous basalts of the Scotian Shelf
}

\author{
G. Pe-Piper \\ Department of Geology, St. Mary's University, Halifax, N.S. B3H 3C3 \\ L.F. Jansa \\ Geological Survey of Canada, Atlantic Geoscience Centre \\ Bedford Institute of Oceanography, Dartmouth, N.S. B2Y $4 A 2$
}

Volcanic rocks are interbedded with late Lower Cretaceous sediments in four wells in the Orpheus Graben, Scotian Shelf. Geochemical analysis of carefully selected chips show that the rocks are alkali basalts, with typical oceanic alkali basalt rare-earth element patterns and trace element geochemistry. Mineralogically, the rocks consist of labradorite-andesine plagioclase, clinopyroxene, and altered olivine, with interstitial $\mathrm{K}$-feldspar, biotite, basaltic hornblende and natrolite. The main identifiable secondary mineral is chlorite. K-Ar dates range from 102 to 119

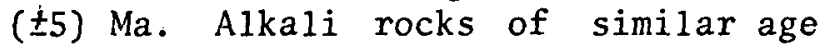
occur in eastern North America. (White Mountains and Monteregian Hills) and also form seamounts in the western North Atlantic (New England Seamounts and Newfoundland Seamounts). The occurrence of similar volcanism near the edge of the continental plate, as well as in the oceanic plate, and the synchronism of the volcanism indicate that all these features are related to a major intraplate volcanic period. The cause of this volcanism is not yet known, but because it influenced both the continental and oceanic crust regions, it has to have a deeper mantle source. The linear arrangement of the occurrence of volcanics in the Orpheus Graben area and elsewhere suggests that the magma followed reactivated tectonic zones.

\section{Graded sand beds on the Scotian Shelf produced by major storms: implications for ancient rocks}

David J.W. Piper, Atlantic Geoscience Centre, Geological survey of Canada Bedford Institute of Oceanography, Dartmouth, N.S. B2Y 4A2 and

Nikos Kontopoulos, Geological Laboratory University of Patras, Patras, Greece

Eight gravity cores have been studied from a transect of the sand-mud transition at the seaward margin of Emerald Basin, a mid-shelf basin on the Scotian Shelf. Over a horizontal distance of 6 $\mathrm{km}$, water depth increases by only about $15 \mathrm{~m}$, but the sand content of surficial sediment decreases from $60 \%$ to $5 \%$. Although the sediment is bioturbated, primary graded bedding is recognizable, with laminated sands at the base of the beds. Beds can be correlated from one core to another, and thicken rapidly basinwards. Dating of the cores by the appearance of European weed pollen suggests that the graded beds are deposited during storms with a recurrence interval of several hundred years. It is suggested that much of the basin sedimentation on the Scotian Shelf may be very episodic.

Similar graded sand beds are common in ancient shelf sediments, for example, the Arisaig section described by Cant (1980). 


\title{
Results of recent mapping in the Newfoundland Appalachians
}

\author{
W.R. Smyth, Newfoundland Department of Mines \& Energy \\ Mineral Development Division, St. John's, Newfoundland AlC $5 T 7$
}

Some of the major results of a five year program of geological mapping carried out by the staff of the Department of Mines and Energy and funded under a joint Federal/Provincial Program are summarized.

Cambro-Ordovician carbonate sedimentation in the Humber Zone in Western Newfoundland occurred in three megacycles, each containing a major marine transgression and regression. Disconformities formed during the regressive stages. Local dolomitization of limestones occurred during the regressions and these dolomites are the locus of Mississippi Valley-type mineralization. The regressions on the platform can be related, on the basis of conodont biostratigraphy, to deposition of limestone reefs in the volcanic arcs of the adjacent Dunnage Zone.

Mapping has confirmed the major subdivisions of the Dunnage Zone in the centre of the island into ophiolitic basement, lower Ordovician island arc, Upper Ordovician shale and flysch, and Upper Ordovician to Silurian shallow water and subaerial volcanics and sediments. Rocks in southwest Newfoundland, previously considered to be Grenville basement are now interpreted as remnants of Lower Ordovician oceanic crust intruded by syntectonic tonalite plutons. The Cape Ray Fault, once interpreted as a cryptic suture, is explained as a strike-slip fault that separates an ophiolite-plutonic subduction related complex to the northwest from an ophiolite-island arc complex to the southeast.

Extensive dismembered ophiolites (previously interpreted as mantle diapirs) have been discovered in the eastern part of the Dunnage Zone. A ring of ophiolites east of Great Burnt Lake may be the remnants of a large thrust sheet, raising the possibility that much of the Dunnage and Gander Zones is allochthonous .

Dating of phyllites in the Dover Fault indicates that the Gander and Avalon Zones were juxtaposed in Devonian times.

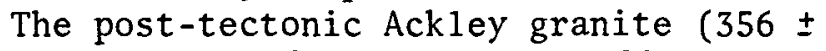
5) cuts the fault and is unaffected by it. A litho-geochemical study of this pluton indicates that high level, ore differentiated phases in the south are anomalous in F, $U$ and $S n$. Mineralized Greisen zones were recently discovered by ground follow-up.

\section{Iceberg scouring and sediment dynamics: seabed processes in the Hibernia area, Grand Banks of Newfoundland}

\author{
C.F.M. Lewis, J.V. Barrie*, G.B. Fader, L.H. King and C.L. Amos \\ Geological Survey of Canada, Atlantic Geoscience Centre \\ Dartmouth, N.S. B2Y $4 A 2$ \\ *C-CORE, Memorial University of Newfoundland \\ St. John's, Newfoundland AlB $3 \times 5$
}

The Hibernia area of northeastern Grand Banks in $80 \mathrm{~m}$ of water depth is subject to iceberg scouring and intermittent hydrodynamic sediment transport, according to evidence on high resolution seismic reflection profiles, sidescan sonar records, bottom photographs, current meter data, sediment analyses, borehole results and submersible obser- vations. Thin discontinuous sand and gravel deposits unconformably overlie eastward-dipping silts and sands of Tertiary age. The sediment at the Tertiary unconformity appears to be overconsolidated, possibly due to erosion, subaerial exposure and desiccation during periods of glacial low sea levels. A minor terrace occurs between 100 and 
110 metres below sea level on the gently sloping northeast Grand Banks margin. Bedforms on and above the terrace, comprising sand ribbons, sand waves, megaripples and wave-induced ripples suggest intermittent sand transport under storm conditions. Below the terrace a thin continuous fine sand facies partially buries a degraded, relic, iceberg-furrowed surface.

A sparse population of relatively fresh iceberg scours comprising linear and curvi-linear furrows and circular pits is superimposed on the relic furrowed surface and the bank margin. This population probably represents the cumulated record of iceberg impacts within the past 10,000 years after late Wisconsin. low sea level had risen sufficiently to allow icebergs to drift onto the Banks. The frequency of groundings deduced from seabed and geological evidence is compared with that inferred from historical iceberg observations. Between 140 and 70 metres of water depth, there is an upslope decrease in iceberg scour depth, width, abundance and in the degree of ice-related seabed distrubance. This is thought to result from a decrease in iceberg size and flux toward the Grand Banks margin away from the major iceberg source - the main branch of the Labrador current flowing around the northeast corner of the Grand Banks. Scour depths may be limited in shoaler water also by strong sediments at the Tertiary surface and by intermittent sedimentary infilling.

\title{
The Stephanian stage, Sydney Coalfield, Nova Scotia
}

\author{
E.L. Zodrow, Department of Geology, College of Cape Breton \\ and. \\ Sydney, N.S. BIP $6 L 2$ \\ R.A. Gastaldo, Department of Geology \\ Auburn University, Auburn, Alabama 38849 USA
}

Study is directed to bio- and chronostratigraphically reappraise the relatively youngest sedimentary rock sequence of Sydney Coalfield (at Point Aconi) using homotaxy. Specifically, the comparative floristic groups include the form genera Pecopteris Brongniart, Odontopteris Brongniart, and Sphenophyllum Koenig, all of which are suited for the purpose. Of the first genus more than 20 species representing six of Corsin's pecopterid groups have been recognized, e.g. Pecopteris saraefolia, $P$. arborescens, $P$. unita, $P$. polymorpha, $P$. plumosa, and $P$. miltoni. The significance of the study is summarized under four categories: (1) Upper Paleozoic compression flora of Eastern Canada is re- evaluated and continued to be documented, (2) quantitative and qualitative analysis of the specimens have allowed recognition of morphological variability within polulations, and in turn, have provided a more accurate concept of these taxa especially in the overspeciated form genus Pecopteris, (3) strata comprising the Sydney Coalfield can be divided according to dominating pteridophyte groups: lower and middle strata are characterized by pteridosperms, and the upper ones by groups 1isted, and (4) a Stephanian age is thus proposed for the Point Aconi section based on increasing diversity and dominance of pecopterids, odontopterids, and sphenopids.

\section{Thrusting tectonics in eastern Notre Dame Bay}

\section{Paul F. Williams, Karl Karlstrom and Ben van der Pluijm}

Department of Geology, University of New Brunswick, Fredericton, N.B. E3B 5A3

Structural analysis of the area examined has produced sufficient geometrical constraints to allow meaningful kinematic modeling.
$F_{1}$ folds are intrafolial and where asymmetry can be determined are markedly asymmetrical in general. In addition, if $F_{2}$ folds are unfolded such that 
bedding is restored to horizontal the $F_{1}$ folds are recumbent. This geometry can only be explained by a kinematic model of heterogeneous flow approximately parallel to bedding. Such a model is consistent with either a soft sediment slumping origin for the folds or with a hard rock origin in a thrusting environment. Such hard rock folds are common as early structures in other areas where thrusting has been an important deformation mechanism (e.g. the Caledonides and the Alps).

$\mathrm{F}_{2}$ folds are hard rock structures and are asymmetrical upward facing folds that are overturned to the north. The overturned limb is weakly deformed whereas the normal limb is very strongly attenuated. The folds have an axial plane foliation and the regional enveloping surface is at most only shallowly dipping. This geometry can be produced by a kinematic model involving an early stage of layer parallel shortening followed by strong, enveloping surface parallel shear. The second part of this model is again indicative of thrusting and since no alternate model has proved satisfactory we believe that $\mathrm{F}_{2}$ folds represent a continuation of the thrusting style of deformation that is responsible for $F_{1}$. In the case of $F_{2}$ there is sufficient evidence to say that thrusting was towards the north-west.

Two other sets of data support the model for $F_{2}$. The grade of regional metamorphism increases towards the southeast and post $F_{2}$ normal faults are believed to be southeast block down.

In summary, kinematic considerations suggest that the area was one in which deformation was principally associated with the emplacement of thrust slices.

\title{
Geological and geothermal effects on coal rank variations in the Pennsylvanian Basin of New Brunswick
}

\author{
P.A. Hacquebard and M.P. Avery \\ Atlantic Geoscience Centre, Geological Survey of Canada \\ Dartmouth, N.S. B2Y $4 A 2$
}

Rank determinations by vitrinite reflectance measurements of thin coals from 162 locations, covering most of the Pennsylvanian Basin, form the data base of this investigation. The reflectance values, projected to sea level position with the Maritime coalification curve, show a systematic pattern. This pattern, as interpreted by trend-surface analyses, indicates a progressive increase in rank, from high volatile "C" bituminous coals in the coastal areas in the east, to anthracite in the region southwest of Fredericton.

Local variations within this regional pattern are present, but in a broad sense the trend conforms with the occurrence of progressively older formations in a southwesterly direction. However, the degree of increasing coalification, to the level of anthracite, cannot be related solely to greater depth of burial and therefore increased geotemperatures in the older formations. Additional sources of heat are required for this, and may have been provided by: nearby igneous rocks or concentrations of radioactive minera1s.

In support of this is the observation that the highest present heat flow in New Brunswick has been recorded at Mt. Pleasant, which is in close proximity to the anthracite occurrences, while abnormal vertical coalification gradients in wells near Fredericton suggest increased temperatures from a radio-active heat source. 


\title{
POSTER SESSION
}

\section{The Cape Breton Granitoid Pluton Project: a progress report}

\author{
Sandra M. Barr \\ Department of Geology, Acadia University, Wolfville, N.S. BOP IXO
}

In 1978, a study of granitoid plutons in Cape Breton Island was initiated in cooperation with the Nova Scotia Department of Mines and Energy. This project involves detailed mapping of the plutons, followed by petrographic studies, age dating, major and trace element analyses, and assessment of economic potential. To date, plutonic rocks have been investigated in thirteen areas (Gillis Mountain, Deep Cove, Petit de Grat, Loch Lomond, Huntington Mountain, Boisdale Hills, Creignish Hills, Kellys Mountain, St. Anns Mountain, Cape Smoky, White Point, Cheticamp, and Whycocomagh Mountain). Four of these have been the subject of M.Sc. or B.Sc. (Honours) thesis projects completed or in progress at Acadia University. Plutonic rocks in the Mabou Highlands will be mapped in 1982 .

These studies have shown that: (1) the plutons fall. into two main age groups, Late Hadrynian-Cambrian and Devono-Carboniferous, although a few may be Ordovician-Silurian; (2) most, but not all, plutons are composite, ranging from diorite to leucogranite or alaskite; (3) in chemistry, the plutons are calc-alkalic and generally display typical calc-alkali differentiation trends; (4) they have affinities with "I-Type" and "magnetite-series" granitoid rocks; (5) their petrographic and chemical features suggest potential for Cu-Mo-W mineralization of porphyry or skarn type, consistent with known mineral occurrences in Cape Breton Island.

\section{Petrology and geochemistry of the River Lake Pluton Halifax County, Nova Scotia}

\author{
Wayne C. Thomas, Department of Geology \\ Acadia University, Wolfville, N.S. BOP IXO
}

The River Lake Pluton is a granitoid stock intruded into lower to middle Cambrian shales and siltstones in eastern Halifax County, Nova Scotia. Petrographic and geochemical studies indicate that the pluton consists of three phases in which the sequence of intrusion is (i) granodiorite (ii) monzogranite (iii) late stage pegmatites and aplites. The pluton exhibits a concentric zonation with the granodiorite forming the outer zone, and the monzogranite the inner core. No contact relation between the pluton and the country rocks or within the pluton itself were seen. Xenoliths are rate to absent. The pluton is displaced by a large. sinistral fault in a NW direction.

Petrographic studies show that both the granodiorite and monzogranite are coarse-grained and consist of plagio- clase (oligoclase/andesine), alkali feldspar, quartz, and mica. In the monzogranite, muscovite is an essential mineral and dominates over biotite. Accessory garnet, apatite and opaques are also present. Alteration is variable, and occurs as sericitization of the feldspars and chloritization of the micas. Geochemical studies indicate that the pluton is peraluminous, with normative corundum in excess of $2 \%$. The granodiorite is the least silicic phase and has relatively high levels of $\mathrm{Fe}_{2} \mathrm{O}_{3}$ (total), $\mathrm{MgO}, \mathrm{MnO}, \mathrm{TiO}_{2}$, and $\mathrm{CaO}$. $\mathrm{Alu}-$ mina values are approximately the same in both phases. Harker variation plots are generally irregular or show very weak trends. Studies of trace element results are still in progress. Initial indications point towards an origin from a metasedimentary source. 


\title{
Southern Cape Breton Highlands Mapping Project
}

\author{
R.A. Jamieson \\ Department of Geology, Dalhousie University, Halifax, N.S. B3H $3 J 5$
}

Recent work in the southern Cape Breton Highlands has focussed on the Middle River - Crowdis Mountain area where a complex late Precambrian to DevonoCarboniferous geological history is preserved. The area is underlain primarily by volcanic and related sedimentary and intrusive rocks, is bounded on the west and east by older high-grade metamorphic rocks and foliated diorites, and intruded by granitic rocks in the north. There are probably two volcanic sequences present, separated by mylonite zones from each other and from metamorphic rocks to the northwest. The probably older northern unit consists mainly of felsic pyroclastic rocks and volcano- genic sediments, which range from mildly to strongly deformed. The probably younger southern unit consists of essentially undeformed rhyolite, mafic flows, and associated pyroclastic and sedimentary rocks. This unit has been dated by $\mathrm{Rb}-\mathrm{Sr}$ at $384 \pm 10 \mathrm{Ma}$ and is thought to be equivalent to the Fisset Brook Formation of western Cape Breton. The volcanic rocks are intruded by monzogranites in the north and a dioritemicrogranite complex in the south. Geochemical, petrological, and geochronological studies of these volcanics are in progress to determine their role in the tectonic evolution of northwestern Cape Breton.

\section{Preliminary testing of very compact seismic profiling equipment with some results from Loch Lubnaig, Scotland}

\author{
Alasdair G. MCKay, 35 Edward St., Dartmouth, N.S. \\ and
}

Iain J. MCEwen, Department of Ghemistry, University of Stirling, Scotland

Sma11, light acoustic profiling equipment has the advantage of easy transportation and installation in very small boats. We carried out tests in May 1981 with a $25 \mathrm{~cm}$ diameter "boomer" type source driven by a 4000 volt triggered capacitor bank for which power was supplied by two car batteries.

Loch Lubnaig is a body of water about $6 \mathrm{~km}$ long and $0.5 \mathrm{~km}$ wide lying in a narrow glaciated valley just north of the Highland Boundary Fault Zone. With the equipment described above installed in a 3-metre long car-top boat we ran one longitudinal and six transverse profiles in the southern half of the loch. In December 1981, a small sediment sampling program confirmed coarse sandy gravel on the flanks of the loch, but the ice cover was insufficiently thick to allow successful sampling through the ice in the deeper (30 metres) central parts of the loch of a bottom material which the seismic record suggest would be much finer. This material from the loch bottom exhibits a series of mounds or waves having a vertical height of 5 metres, whose origin is obscure at present. 